\title{
EVALUATION OF ANTICONVULSANT ACTIVITY OF PREMNA HERBACEA (ROXB.) ROOT EXTRACTS IN ISONIAZID AND STRYCHNINE-INDUCED CONVULSIONS
}

\author{
CHIMBALKAR AD ${ }^{1 *}$, VYAWAHARE NS ${ }^{2}$ \\ ${ }^{1}$ Department of Pharmacy, Ponnaiyah Ramajayam Institute of Science and Technology University, Thanjavur, Tamil Nadu, India. \\ Department of Pharmacy, Dr. D. Y. Patil College of Pharmacy, Pune, Maharashtra, India. Email: neerajsv@rediffmail.com
}

Received: 02 June 2018, Revised and Accepted: 18 August 2018

\section{ABSTRACT}

Objective: The present investigation was to evaluate the anticonvulsant potential of three different extracts of roots of Premna herbacea (Roxb.) in mice. The preclinical screening models such as isoniazid (INH)- and strychnine (STR)-induced convulsion were selected for the study.

Methods: The three different extracts of P. herbacea, i.e., ethanolic (PHE), petroleum ether (PHP), and chloroform (PHC) were prepared as per standard procedures and evaluated at three different doses $(100,200$, and $400 \mathrm{mg} / \mathrm{kg})$ and screened with above-mentioned INH and STR-induced convulsions.

Results: In INH model, PHC $200 \mathrm{mg} / \mathrm{kg}$ and $400 \mathrm{mg} / \mathrm{kg}$ showed dose-dependent delay in onset of convulsion $(\mathrm{p}<0.05$ and $\mathrm{p}<0.01)$ along with protection of $33.33 \%$ of mice. The PHP $400 \mathrm{mg} / \mathrm{kg}$ also showed a significant delay in the onset of convulsion ( $\mathrm{p}<0.05$ ) along with protection of $16.66 \%$ of mice. In STR-induced model, none of the extracts was effective to delay the onset of convulsion; however, PHC $400 \mathrm{mg} / \mathrm{kg}$ protected $16.66 \%$ of mice.

Conclusion: The results confirmed dose-dependent anticonvulsant activity of $P$. herbacea PHC in INH-induced convulsions.

Keywords: Anticonvulsant, $P$. herbacea root extract, Strychnine, Isoniazid.

(c) 2018 The Authors. Published by Innovare Academic Sciences Pvt Ltd. This is an open access article under the CC BY license (http://creativecommons. org/licenses/by/4. 0/) DOI: http://dx.doi.org/10.22159/ajpcr.2018.v11i12.28174

\section{INTRODUCTION}

Epilepsy is the disorder of the brain characterized by recurrent seizure of cerebral origin [1]. It is the second most common chronic neurological condition observed worldwide [2]. It affects approximately $1 \%$ of population which results in $3 \%$ of cumulative incidences $[3,4]$.

The prevalence of epilepsy is higher in the developing countries such as India than developed countries [5]. Despite the availability of a large number of antiepileptic drugs in modern medicine, approximately $30 \%$ of patients show poor response to the therapy, especially longterm administration leading to recurrence [6,7]. High-cost, wide range of untoward effect, and development of tolerance are few other limitations [8]. Hence, search is continued to develop newer, more effective, and safe anticonvulsant agent.

Medicinal plant with traditional claim and being used since long has become the preferred target for development if an ideal drug [9]. Inherently margin, better effect, and wider safety on complaints with complex pathogenesis mostly due to the synergistic action of multiple phytoconstituents which increase advantages of medicinal plants [10].

As per literature survey, Premna herbacea is an important medicinal plant traditionally claimed for its usefulness in a variety of conditions including epilepsy. Further, its claim as an analgesic, anti-inflammatory, and antiulcer has been validated scientifically $[11,12]$. The roots of $P$. herbacea have been claimed to be useful in convulsions, however, yet not documented scientifically [13]. Hence, it was thought worthwhile to study the anticonvulsant activity of $P$. herbacea in mice to confirm the previous claim and its scientific documentation suggesting its potential anticonvulsant activity with lesser side effects.

\section{MATERIALS AND METHODS}

Preparation of extracts

The entire plant of $P$. herbacea (Roxb.) was collected from the Southern Ghats region and authenticated by Dr. K. Madhawa Chetty, at Shri
Venkateswara University, Tirupati. The roots of the collected plants were carefully separated shade-dried and powdered. This powder was passed through a sieve (No. 40) and then subjected to extraction using Soxhlet apparatus with $70 \%$ ethanol $(100 \mathrm{~g}$ in $500 \mathrm{~mL})$, petroleum ether and chloroform at a temperature $<20^{\circ} \mathrm{C}$. After filtration, dark brown extract was evaporated at $50^{\circ} \mathrm{C}[14]$.

\section{Animals}

Swiss albino mice (18-25 g) of either sex were procured from M/s. National Toxicological Center, after obtaining the approval of the Institutional Animal Ethics Committee (RP-19/1516). The mice were acclimatized to the laboratory environment, provided with standard pellet diet and water ad libitum.

\section{Drugs and chemicals}

Pentylenetetrazol was purchased from Sigma, St. Louis, USA, isoniazid (INH) and strychnine (STR) from Sigma, St. Louis, USA, and diazepam from Ranbaxy, India. All chemicals and drugs were made available by local vendor.

\section{Statistical analysis and calculations}

Results were expressed as mean \pm standard error. Statistical analysis was performed using one-way analysis of variance followed by Dunnett's test. $\mathrm{P}<0.05$ was considered as statistically significant.

\section{Methods}

Preliminary phytochemical analysis

Preliminary phytochemical analysis of all three extracts was carried out using established methods to record the presence of phytochemicals [15].

Determination of acute toxicity study $\left(\mathrm{LD}_{50}\right)$

The acute toxicity for all three extracts was performed as per the OECD guideline no 423 [16]. 
Table 1: Effects of Premna herbacea extracts on INH-induced convulsions

\begin{tabular}{llll}
\hline Groups & Treatment & Onset of convulsion (s) (mean \pm SEM) & Number of mice survived after 24 h \\
\hline I & Control distilled water $10 \mathrm{ml} / \mathrm{kg}$ & $1224.68 \pm 18.122$ & 0 \\
II & Diazepam $5 \mathrm{mg} / \mathrm{kg}$ & $1488.61 \pm 21.96$ & 5 \\
III & PHE $100 \mathrm{mg} / \mathrm{kg}$ & $1219.67 \pm 26.13$ & 0 \\
IV & PHE $200 \mathrm{mg} / \mathrm{kg}$ & $1203.30 \pm 12.92$ & 0 \\
V & PHE $400 \mathrm{mg} / \mathrm{kg}$ & $1201.69 \pm 20.22$ & 1 \\
VI & PHP $100 \mathrm{mg} / \mathrm{kg}$ & $1192.49 \pm 10.54$ & 0 \\
VII & PHP $200 \mathrm{mg} / \mathrm{kg}$ & $1223.00 \pm 20.91$ & 0 \\
VIII & PHP $400 \mathrm{mg} / \mathrm{kg}$ & $1304.31 \pm 20.26^{*}$ & 1 \\
IX & PHC $100 \mathrm{mg} / \mathrm{kg}$ & $1201.77 \pm 13.94$ & 0 \\
X & PHC $200 \mathrm{mg} / \mathrm{kg}$ & $1304.54 \pm 10.98^{*}$ & 2 \\
XI & PHC $400 \mathrm{mg} / \mathrm{kg}$ & $1350.89 \pm 21.86^{* *}$ & 2 \\
\hline
\end{tabular}

The values are represented as mean \pm SEM $(\mathrm{n}=6)$. SEM: Standard error mean, P. herbecea: Premna herbecea, PHE: Ethanolic extract of $P$. herbacea, PHP: Petroleum ether extract of $P$. herbacea, PHC: Chloroform extract of $P$. herbacea, INH: Isoniazid

Table 2: Effects of Premna herbacea on STR-induced convulsions

\begin{tabular}{llll}
\hline Groups & Treatment & $\begin{array}{l}\text { Onset } \\
\text { latency (s) }\end{array}$ & $\begin{array}{l}\% \\
\text { Protection }\end{array}$ \\
\hline I & Distilled water $10 \mathrm{ml} / \mathrm{kg}$ & $154.08 \pm 03.23$ & 0 \\
II & Diazepam $5 \mathrm{mg} / \mathrm{kg}$ & $316.89 \pm 09.63$ & 83.33 \\
III & PHE $100 \mathrm{mg} / \mathrm{kg}$ & $154.51 \pm 03.30$ & 0 \\
IV & PHE $200 \mathrm{mg} / \mathrm{kg}$ & $153.99 \pm 03.04$ & 0 \\
V & PHE $400 \mathrm{mg} / \mathrm{kg}$ & $155.02 \pm 02.83$ & 0 \\
VI & PHP $100 \mathrm{mg} / \mathrm{kg}$ & $152.73 \pm 03.13$ & 0 \\
VII & PHP $200 \mathrm{mg} / \mathrm{kg}$ & $151.92 \pm 02.06$ & 0 \\
VIII & PHP $400 \mathrm{mg} / \mathrm{kg}$ & $156.37 \pm 03.76$ & 0 \\
IX & PHC $100 \mathrm{mg} / \mathrm{kg}$ & $157.37 \pm 04.17$ & 0 \\
X & PHC $200 \mathrm{mg} / \mathrm{kg}$ & $155.88 \pm 03.49$ & 0 \\
XI & PHC $400 \mathrm{mg} / \mathrm{kg}$ & $157.24 \pm 03.32$ & 16.66 \\
\hline
\end{tabular}

The values are represented as mean \pm SEM $(n=6)$. SEM: Standard error mean, $P$. herbecea: Premna herbecea, PHE: Ethanolic extract of $P$. herbacea, PHP: Petroleum ether extract of $P$. herbacea, PHC: Chloroform extract of P. herbacea, STR: Strychnine

Table 3: Preliminary phytochemical analysis of $P$. herbecea

\begin{tabular}{llll}
\hline Phytochemical & PHE & PHP & PHC \\
\hline Carbohydrates Carbohydrates & ++ & - & - \\
Protein & + & - & + \\
Amino acids & - & - & - \\
Fats and oils & - & - & - \\
Steroids & + & + & ++ \\
Volatile oils & - & - & + \\
Cardiac glycosides & + & - & - \\
Anthraquinone glycosides & - & - & + \\
Cyanogenetic glycosides & - & - & - \\
Coumarin glycosides & + & - & + \\
Saponins & + & - & - \\
Flavonoids & - & - & - \\
Alkaloids & - & - & - \\
Tannins and phenolic compounds & + & + & + \\
\hline
\end{tabular}

P. herbecea: Premna herbecea, PHE: Ethanolic extract of $P$. herbacea,

PHP: Petroleum ether extract of $P$. herbacea, PHC: Chloroform extract of

P. herbacea

\section{Anticonvulsant activity of INH-induced convulsions}

The 66 pre-selected mice of either sex (18-22g) were divided into eleven groups each consisting six mice. All these mice were subjected to respective treatment as mentioned in Table 1., for the period of 7 days. On the $7^{\text {th }}$ day 60 min after dosing, all mice were subjected to intraperitoneal injection of INH $(300 \mathrm{mg} / \mathrm{kg})$, and the onset of convulsion and percentage protection were recorded and compared against vehicle-treated control mice. Diazepam $(5 \mathrm{mg} / \mathrm{kg})$ was used as a reference standard $[17,18,19]$.

\section{Anticonvulsant activity of STR-induced convulsions}

66 pre-selected mice of either sex (18-22 g) were divided into eleven groups each consisting six mice. All these mice were subjected to respective treatment as mentioned in Table 2., for the period of 7 days. On the $7^{\text {th }}$ day $60 \mathrm{~min}$ after dosing, all mice were subjected to intraperitoneal injection of STR $(2 \mathrm{mg} / \mathrm{kg})$, and the onset of convulsion and percentage protection of mice were recorded and compared against vehicle-treated control mice. Diazepam $(5 \mathrm{mg} / \mathrm{kg}$ ) was used as a reference standard $[19,20]$.

\section{RESULTS}

\section{Preliminary phytochemical analysis}

The preliminary phytochemical analysis revealed the prominent presence of steroids, glycosides, and saponins which is biologically important. A detail analysis is tabulated in Table 3.

\section{Acute oral toxicity study}

The study reported that all three extracts are devoid of any toxicity as no mortality is reported at a dose of $2000 \mathrm{mg} / \mathrm{kg}$.

\section{Anticonvulsant activity}

\section{INH-induced convulsions}

Intraperitoneal injection of INH is used to induce convulsions in all the mice. The vehicle-treated control group mice showed the onset of convulsions at $1224.68 \pm 18.122 \mathrm{~s}$ which was significantly delayed $1304.31 \pm 20.26 \mathrm{~s}$ by petroleum ether of $P$. herbacea (PHP) $400 \mathrm{mg} / \mathrm{kg}$. The chloroform extract of P. herbacea (PHC) $200 \mathrm{mg} / \mathrm{kg}$ and $400 \mathrm{mg} / \mathrm{kg}$ doses show dose-dependent delay to $1300.54 \pm 10.98$ $\mathrm{s}$ and $1350.89 \pm 21.86 \mathrm{~s}$, respectively. However, PHC $200 \mathrm{mg} / \mathrm{kg}$ and $400 \mathrm{mg} / \mathrm{kg}$ was exponent toward percentage protection of animals and protected $16.66 \%$ of mice.

The Ethanolic extract of $P$. herbacea (PHE) $400 \mathrm{mg} / \mathrm{kg}$ also protected $16.66 \%$ of mice. The reference standard diazepam was the most effective in delaying the onset of convulsions $1488.61 \pm 21.96 \mathrm{~s}$ and protecting the mice $(83.33 \%)$

\section{STR-induced convulsions}

Subcutaneous administration of STR induced convulsions in all mice. None of extracts could significantly delay the onset of convulsion as compared to vehicle-treated mice; however, PHC $400 \mathrm{mg} / \mathrm{kg}$ protected $16.66 \%$ of mice. Reference standard diazepam significantly delayed the onset of convulsions to $222.57 \pm 4.85 \mathrm{~s}$ as compared to vehicle-treated control mice, i.e., $141.16 \pm 03.34 \mathrm{~s}$ and protected $83.33 \% \mathrm{~s}$ of mice.

\section{DISCUSSION}

Considering the adverse effects of the drugs used in the treatment of convulsion $[21,22]$ and since primitive times, humans have used natural products, such as plants, animals, microbes, and aquatic organisms, in medicines to improve and treat diseases and disorders. According to the records, the human used plants as medicines from ancient times at least 60,000 years back [23,24]. Many traditional medicines originated from the plants have been used in the treatment of CNS disorders in the Indian Traditional Medicine; however, very few 
of these plants have been evaluated preclinically to prove the rational use $[25,26]$.

The rich and diverse plant sources in India are likely to provide effective drugs [27]. One of the best approaches in the search for drugs from plant resources is the selection of plant-based on ethnomedical leads [28]. Plants contain numerous constituents known as phytochemicals with varied medicinal values. Moreover, the claims made in the traditional literature are indistinguishable [29]. Hence, scientific validation of these claims is necessary to make therapy more effective and patient-friendly. The present study has been conducted to coordinate the traditional claim, experimental observations, and role of phytochemicals to establish its close relationship toward the actual therapeutic outcome. In the present investigation, preliminary phytochemical analysis of PHE showed the presence of glycosides, flavonoids, tannins, and steroids, while PHP reported prominent presence of steroids and proteins; steroids, anthraquinone, and coumarin glycosides were found in PHC. The earlier scientific studies have revealed that most of these phytochemicals are chiefly responsible for the pharmacological actions [30-32] and thereby suggested worth to explore the traditional claims [33]. Toxicity is one of the most important aspects of any medication to govern the extent of therapeutic utility [34]. Since preliminary phytochemical results gave indication of further pharmacological screening, it becomes mandatory to evaluate these extracts for their toxicity profile and confirm its safety [35]. The acute oral toxicity study of PHE, PHP, and PHC revealed that all these extracts are safe to be used as drug. The results of acute oral toxicity study further suggested that these extracts can be screened preclinically for validation of its traditional claim in accordance with the methods mentioned in previously published reports. Further, the pilot study and dose range were found to be effective without any toxic outcome in earlier published reports, and three different doses, i.e., 100, 200, and $400 \mathrm{mg} / \mathrm{kg}$ for each extract were selected for anticonvulsant activity [35]. The findings of these studies suggest that PHC possess significant anticonvulsant activity against INH-induced convulsions. Since INH interferes with GABA synthesis through inhibition of glutamic acid decarboxylase resulting into rapid depletion of GABA which causes the potentiation of GABA transmission or prevention of its depletion is the probable mechanism of action. Diazepam is widely accepted for this type of epilepsy which has sedation and tolerance as major limitations. In the pilot study and during regular pretreatment, none of the extract of PH showed any sign of sedation which perhaps could be the major advantage of it over diazepam and outcome of this study. Saponin, steroid, and flavonoids are prominently responsible for anticonvulsant activity. The preliminary phytochemical analysis showed the presence of steroids in PHC only, while saponin was present in both PHE and PHP, suggesting major role of steroid in action. Since saponin was present, PHP $400 \mathrm{mg} / \mathrm{kg}$ and PHE $400 \mathrm{mg} / \mathrm{kg}$ were found to be effective in delaying onset and protecting mice, respectively. STR induces seizures by competitively antagonizing inhibitory amino acid glycine.

In STR model, none of the extracts showed any significant effect, suggesting non-involvement glycine-mediated inhibition in its anticonvulsant activity.

\section{CONCLUSION}

It can be concluded form the study that chloroform extract of $\mathrm{PH}$ possesses anticonvulsant activity against INH-induced convulsion. This effect may be due to the prevention of GABA depletion and potentiation of GABA and attributed to the steroidal content of the extract.

However, further detail study is required to establish the precise mechanism of action and role of exact phytoconstituent.

\section{ACKNOWLEDGMENT}

Authors are thankful to the National Toxicological Institute for the provision of facility to carry out experiments as well as PRIST University for their valuable support.

\section{AUTHORS' CONTRIBUTION}

Performed collection of sample, extraction, analysis, and statistical analysis of data and wrote the manuscript. The second author supervised the progress of work and helped in the evaluation of the manuscript and its language corrections.

\section{CONFLICTS OF INTEREST}

Authors declare no conflicts of interest.

\section{REFERENCES}

1. Delgado-Escueta AV, Treiman DM, Walsh GO. The treatable epilepsies. N Engl J Med 1983;308:1508-14.

2. England MJ, Liverman CT, Schultz AM, Strawbridge LM. Epilepsy Across the Spectrum: Promoting Health and Understanding. Washington (DC): National Academies Press (US); 2012.

3. Rout SK, Kar DM. A review on antiepileptic agents, current research and future prospectus on conventional and traditional drugs. Int $\mathrm{J}$ Pharm Sci Rev Res 2010;3:19-3.

4. Mac TL, Tran DS, Quet F, Odermatt P, Preux PM, Tan CT. Epidemiology, etiology and clinical management of epilepsy in Asia: A systematic review. Lancet Neurol 2007;6:533-43.

5. Shridharan R, Murthy BN. Prevalence and pattern of epilepsy in India. Epilepsia 1999;40:631-6.

6. Ezekiel I, Mabrouk MA, Ayo JO, Goji AD, Okpanachi AO, Mohammed A, et al. Study of the effect of hydro-ethanolic extract of Commiphora Africana (stem-bark) on sleeping time and convulsion in mice. Asian J Med Sci 2010;2:85-8.

7. Joy PP, Thomas J, Mathew S, Skaria BP. Medicinal Plants Tropical Horticulture. Vol. 2. Calcutta: Naya Prokashan; 2001.

8. Maiha BB, Magaji MG, Yaro AH, Ahemd ST, Hamza AH, Magaji RA. Anticonvulsant studies on Cochlospermum tinctorium and Paullinia piñata extracts in laboratory animals. Nigern J Pharm Sci 2009;8:102-8.

9. Wannang NN, Anuka JA, Kwanashie HO, Gyang SS, Auta A. Antiseizure activity of the aqueous leaf extract of Solanum nigrum linn (solanaceae) in experimental animal. Afr Health Sci 2008;8:74-9.

10. Suresh K. Plants and plant products with potential anticonvulsant activity - a review. Pharmacogn Commun 2012;2:3-99.

11. Moldenke HN. A sixth summary of the Verbenaceae, avicenniaceae, Stilbaceae, chloanthaceae, symphoremaceae, nyctanthaceae and Eriocaulaceae of the world as to valid taxa, geographic distribution and synonymy. Phytol Mem 1980;2:284-5.

12. Thai Plant Names Tem Smitinand. The Forest Herbarium. Bangkok: Royal Forest Department Revised Edition; 2001. p. 810.

13. Nadkarni AK. Indian Material Medica. New Delhi: Popular Prakashan; 1985. p. 1008

14. Lolita T, Zanda K, Galoburda R. Comparison of different solvents and extraction methods for isolation of phenolic compounds from horseradish roots (Armoracia rusticana). Int J Biol Biomol Agric Food Biotechnol Eng 2012;6:236-41.

15. Khandelwal KR. Practical Pharmacognocy. Mumbai: Pragati Books Pvt. Ltd.; 2008.

16. OECD. Guideline on Acute Oral Toxicity, Environmental Health and Safety Monograph Series on Testing and Adjustment No 423; 2001.

17. Vogel HG, Gang HW. Drug Discovery and Evaluation Pharmacological Assays. $4^{\text {th }}$ ed. New York: Springer-Verlag Berlin Heidelberg; 2002.

18. Nandakumar J, Manoj GT. Evaluation of cyclic nucleotide phosphodiesterase III inhibitors in animal models of epilepsy. Biomed Res 2008;19:13-7.

19. Alice AL, Elvin JB. Glycine potentiates strychinine-induced convulsions: Role of NMDA receptoe. J Neurosci 1988;8:3823-26.

20. Curtis DR, Game CJ, Lodge D. Benzodiazepines and central glycine receptors. Br J Pharm 1976;56:307-11.

21. Gupta YK, Malhotra J. Adenosinergic system as an endogenous anticonvulsant mechanism. J Physilol Pharmacol 1997;41:329-43.

22. Henry D, Sylvia A, Chidambaranathan S, Nirmala P. A prospective study of drug utilization pattern of anti-epileptic drugs and their adverse effects in a tertiary care hospital. Int J Curr Pharm Res 2017;9:42-5.

23. Shi QW, Li LG, Huo CH, Zhang ML, Wang YF. Study on natural medicinal chemistry and new drug development. Chin Tradit Herb Drugs 2010;41:1583-9.

24. Fabricant DS, Farnsworth NR. The value of plants used in traditional medicine for drug discovery. Environ Health Perspect 2001;109:69-75.

25. Mukherjee DG, Dey CD. Clinical trial on Brahmi. India J Exp Med Sci 
1996;10:5-8.

26. Madhavi E, Gopala RK, Ruckmani A, Umar D. Evaluation of antiepileptic activity of ethanolic extract of Azima tetracantha root in mice. Int J Curr Pharm Res 2016;8:76-9.

27. Dwyer AV, Whitten DL, Hawrelak JA. Herbal medicines, other than St. John's Wort, in the treatment of depression: A systematic review. Altern Med Rev 2011;16:40-9.

28. Katiyar C, Gupta A, Kanjilal S, Katiyar S. Drug discovery from plant sources: An integrated approach. Ayu 2012;33:10

29. Dahanukar SA, Kulkarni RA, Rege NN. Pharmacology of medicinal plants and natural products. Indian J Pharmacol 2000;32:S81-118.

30. Chaulya NC, Haldar PK, Mukherjee A, Khanra R, Chakraborty A. Anticonvulsnt acivity of methanolic extract of Rhizomes of Cyperus tegetum Roxb. J Pharm Sci Tec 2011;1:1-5.

31. Nimbal SK, Vekatrao N, Basaavraj P, Shalam, Ladde S. Evaluation of anticonvulsant activity of alcoholic extract of Beninkasa hispida (Thunb) cogn. Fruit extracts. Int Res J Pharm 2011;2:166-8.

32. Atigari DV, Gundamaraju R, Sabbithi S, Chaitanya KB, Ramesh C. Evaluation of antiepileptic activity of methnolic extract of Celastrus paniculatus, Wild whole plant in rodents. Int J Pharm Phytopharmacol Res 2012;2:20-5.

33. Gogte HN. Ayurvedic Pharmacology and Therapeutic uses of Medicinal Plant. New Delhi: Drvyagunavidnyana, Chaukhamba Publication; 2009. p. 450-3

34. Rang HP, Ritter JM, Flower RJ, Bookmark G. Pharmacology. $5^{\text {th }}$ ed. London: Churchill Livingstone; 2003.

35. Thirumalai D, Paridhavi M, Gowtham M. Evaluation of physiochemical, pharmacognostical and phytochemical parameters of Premna herbacea. Asian J Pharm Clin Res 2013;6:1173-81. 